\title{
Discontinuous terrain deformation - forecasting and consequences of their occurrence for building structures
}

\author{
Leszek Szojda ${ }^{1, *}$, and Grzegorz Wandzik ${ }^{1}$ \\ ${ }^{1}$ Silesian University of Technology, Department of Structural Engineering, 44-100 Gliwice, Polska
}

\begin{abstract}
The paper is devoted to the influence of mining origin discontinuous deformations of on buildings. In the first part the forms of deformations, their classification, examples and reasons of their formation is discussed. It is supplemented with other classification (cited from literature) related to risk for buildings with regard to the type and intensity of deformation. In the next part, examples of damages of three various buildings located in zones of faults and sinkholes. They were: simple detached house, multi-storey and hall buildings. All of them were the subject of expertizes prepared by the authors. The type of influences and the nature of damages are illustrated with photographs and discussed. In the last part the threats due to the nature of the buildings - their height and size - are discussed. The influence of the location of deformation edge (fault, sinkhole, terrain step) in relation to the object is shortly analyzed. Examples of normal stress distribution in subsoil obtained in numerical calculations have been briefly presented. Some attention have been also paid on protection methods and their effectiveness.
\end{abstract}

\section{Introduction}

In Poland, more than $80 \%$ of electricity is produced from coal, mainly from hard coal. Despite the growing ecological awareness, the change of energy production system will not take place immediately, and a relatively long period of hard coal mining must be expected. Currently, the operation is mainly carried out in the Upper Silesia. Simultaneously, this area is one of the most urbanized, and the conducted exploitation leads to deformations at terrain surface in the consequence affecting the condition of buildings and technical infrastructure.

Hard coal mining leads to several inconveniences. One of the underground exploitation effects is the creation of various types of land deformations. They lead to damage to the existing building infrastructure and therefore require expenses related to the repair of existing facilities. It also requires expenses for securing all newly constructed objects.

Extraction of hard coal deposits in Upper Silesia is accompanied by the formation of two basic types of terrain deformation: continuous and discontinuous. The most common form is the gentle subsidence basin classified as continuous deformations. Little bit less frequently discontinuous deformations are observed as well as some other phenomena

\footnotetext{
${ }^{*}$ Corresponding author: Leszek.Szojda@polsl.pl
} 
associated with subsidence (e.g. changes in water conditions in the substrate). All these influences affect building objects, however, in this paper, attention will be focused only on discontinuous deformations, because threats resulting from these deformations are severe. Simultaneously, investment in such an areas within Upper Silesia are more and more often met.

During many years of observation methods that allow a fairly precise forecasting of continuous deformations have been developed. Simultaneously methods of design and securing buildings against their influence have been elaborated.

\section{Discontinuous deformation - short description}

The discontinuous deformations are much more incomprehensible. In some areas, they occurs in the result of shallow retention of coal deposits while in others as a consequence of specific geological structure of the rock above the seam. Due to the abruptness, discontinuous deformations are much more inconvenient than continuous ones. Prediction of their localization, direction and intensiveness makes that protection of building structures is distinctly more complicated. They can be characterized by the following attributes:

- in contrary to continuous deformation, they are not associated with each mining activity,

- they may occur immediately after operation, as well as several years after its completion,

- their appearance is not preceded by earlier symptoms,

- they are very sudden phenomena (they reveal in several minutes, hours, rarely few days),

- the extend of these deformations are local.

Due to reasons mentioned above it is very difficult to protect buildings and technical infrastructure if they are located in an area where such deformations may occur.

In result of long-term observations it was found that discontinuous deformations can be induced by:

- exploitation of shallow deposits with seem roof collapse,

- violation of the equilibrium in the rock mass in the region of shallow natural or anthropogenic voids,

- puncture of fault zones with mine workings,

- any works in outcrop zones,

- fires in the remains of the seams lying at small depths,

- overlapping exploitation edges of several seams,

- sinkholes formed through the process of mechanical suffosion.

The greatest threat to the occurrence of discontinuous deformations is related to the collapse exploitation of shallow coal seams. As the deeper deposits get under way, this cause no longer occurs. Currently, the most frequent cause of these deformations is the activation of shallow residual voids, less often natural voids.

Discontinuous deformations can be divided into two basic types:

- planar deformations,

- linear deformations.

Discontinuous deformations of the planar type are usually associated with the occurrence of voids in the rock mass. Their form depends on the physicochemical properties of the rock layers located above the emptiness. In the case of non-cohesive soils, conical funnels usually form. In cohesive soils the regular basins form with irregularly shaped parts in the brittle overburden. In the area of the Upper Silesian Coal Basin (USCB), discontinuous deformations of the planar type are found in its northern part. It is associated 
with the occurrences of outcrops of coal seams presence and deposits of zinc and lead ores. In the remaining part of USCB, usually discontinuous deformations of linear type are encountered.

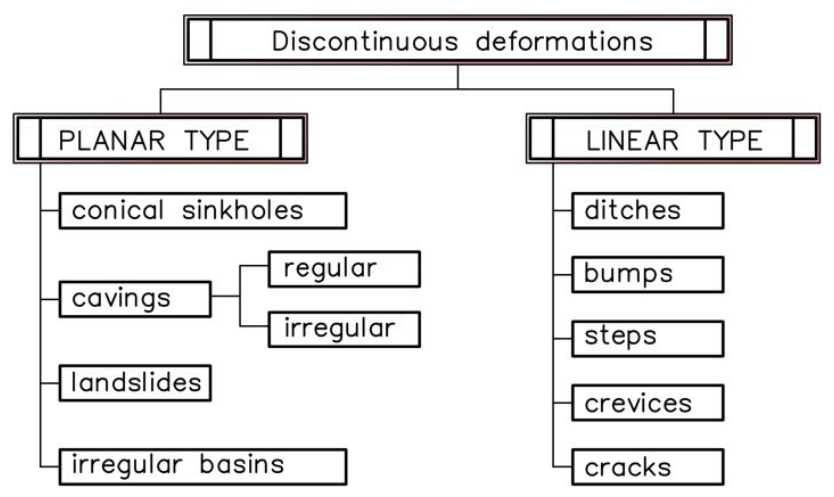

Fig. 1. Types of discontinuous deformations [1].

Depending on the size of the forecasted deformations, it is possible to classify the risk of buildings damages located in such areas using the scale presented below. In an optional proposal suggested in [2] these threats are expressed with grades $G$. This proposition is shown in tabular form - see Table 1.

Table 1. Grades of threats for buildings under discontinuous deformations according to [2].

\begin{tabular}{|c|c|c|c|c|c|}
\hline \multirow{3}{*}{$\mathrm{G}$} & \multirow{3}{*}{$\begin{array}{c}\text { Class of } \\
\text { discontinuous } \\
\text { deformations }\end{array}$} & \multicolumn{3}{|c|}{$\begin{array}{l}\text { Size of the discontinuous } \\
\text { deformation }\end{array}$} & \multirow{3}{*}{$\begin{array}{l}\text { Description of } \\
\text { buildings threats }\end{array}$} \\
\hline & & Planar & & & \\
\hline & & $\begin{array}{l}\text { Sinkhole } \\
\text { diameter } \\
d[\mathrm{~m}]\end{array}$ & $\begin{array}{l}\text { Crevice } \\
\text { width } \\
s[\mathrm{~m}]\end{array}$ & $\begin{array}{l}\text { Step } \\
\text { height } \\
h[\mathrm{~m}]\end{array}$ & \\
\hline 1 & Small $\left(N_{m}\right)$ & $\leq 3.0$ & $\leq 0.05$ & $\leq 0.05$ & $\begin{array}{l}\text { Not dangerous for protected } \\
\text { or even insufficiently } \\
\text { protected buildings when } \\
\text { discontinuous deformations } \\
\text { are not too dense. Dangerous } \\
\text { for linear objects. }\end{array}$ \\
\hline 2 & Moderate $\left(N_{\dot{s}}\right)$ & $\begin{array}{c}3.0 \div \\
9.0\end{array}$ & $\begin{array}{c}0.05 \div \\
0.15\end{array}$ & $\begin{array}{c}0.05 \div \\
0.10\end{array}$ & \begin{tabular}{lrr} 
Dangerous & for & all \\
insufficiently & \multicolumn{2}{c}{ protected } \\
buildings or & even well \\
protected & \multicolumn{2}{c}{ when } \\
discontinuous deformations \\
are densely localized.
\end{tabular} \\
\hline 3 & Large $\left(N_{d}\right)$ & $\begin{array}{r}9.0 \div \\
18.0\end{array}$ & $\begin{array}{c}0.15 \div \\
0.25\end{array}$ & $\begin{array}{c}0.10 \div \\
0.25\end{array}$ & $\begin{array}{l}\text { Not dangerous only for well } \\
\text { protected objects. }\end{array}$ \\
\hline 4 & $\begin{array}{l}\text { Very large } \\
\qquad\left(N_{b d}\right)\end{array}$ & $>18.0$ & $>0.25$ & $h>0.25$ & $\begin{array}{l}\text { Dangerous for all objects, } \\
\text { even those which have been } \\
\text { protected. }\end{array}$ \\
\hline
\end{tabular}




\section{Examples of damages caused by discontinuous deformations}

Damages of building structures occurring due to discontinuous deformations are strongly dependent on the intensity of these deformations. In some cases, structure damages are possible to repair and the building renovation is reasonable. Nevertheless, the authors have encountered many examples in which damages were so significant that repair was totally unfounded. In such cases, the decision of object demolishing is usually made. Below, three different examples of buildings subjected to the influence of discontinuous deformations is presented.

\subsection{Single-family detached house several times subjected to the terrain fault}

The object is a two-storey residential building with a basement in part of it. It consists of two independent parts, separated one from another. The first of them (the main part of the building) was erected in 1938, while the second one was added in 1962. The main part of the building is characterized by a compact plan in a shape of a square with dimensions of $10.53 \times 10.98 \mathrm{~m}$ in the outer contour. The second part is a small porch localized on the north-west side with dimensions $3.20 \times 8.33 \mathrm{~m}$ in the plan. Basements are located under the entire porch and partially under the main part of the object, covering about $25 \%$ of its area. The building was erected in traditional technology. The walls were made of solid bricks. External walls are $51 \mathrm{~cm}$ thick in the basement level and $38 \mathrm{~cm}$ in all levels above the ground. The main part of the building was built on slag and lime strip foundation with the width equal to the basement walls. Floor over the basement were made of steel I-beams with $0,9 \mathrm{~m}$ spacing joined with brick vaults. Above the ground, floor structure is composed of timber beams. The wooden structure roof of the building is the hipped style. The ground and first floor storeys heights are similar and amount to respectively $3.04 \mathrm{~m}$ and $2.90 \mathrm{~m}$. The total height of the building measured from the ground level is approximately $9.0 \mathrm{~m}$.

The plan view of the building basement is shown in Fig. 2. The fault location is also shown in this drawing. This case was prepared on the basis of [3].

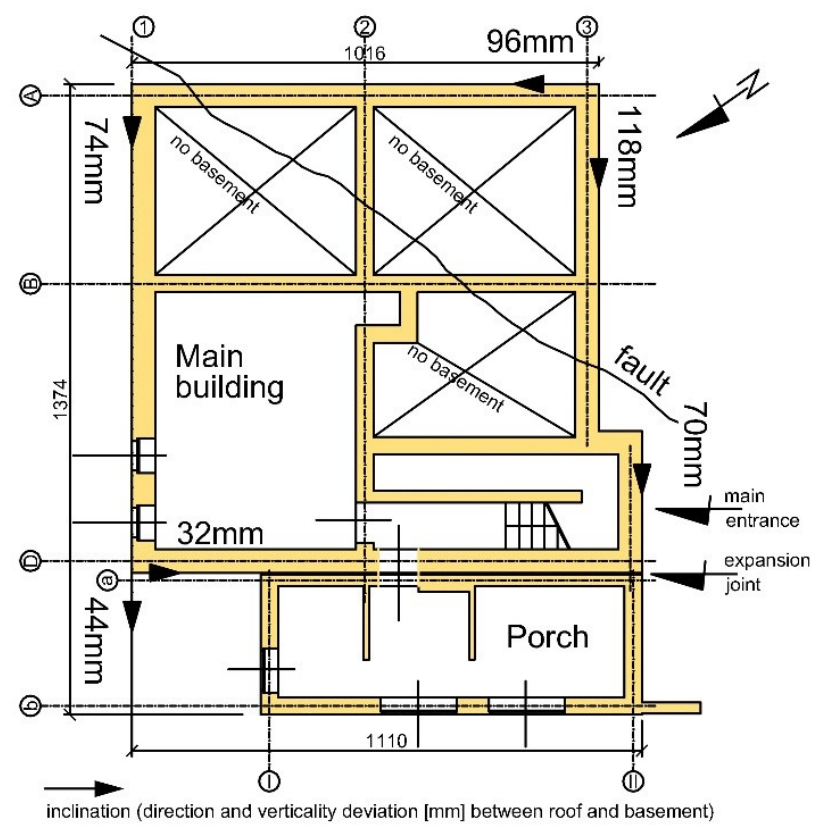

Fig. 2. The basement walls plan and fault location [3]. 


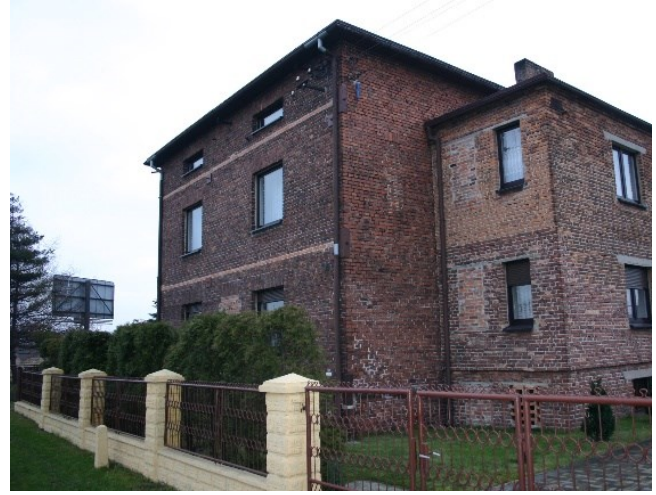

Fig. 3a. View of the building with strengthening in the floor level [3].

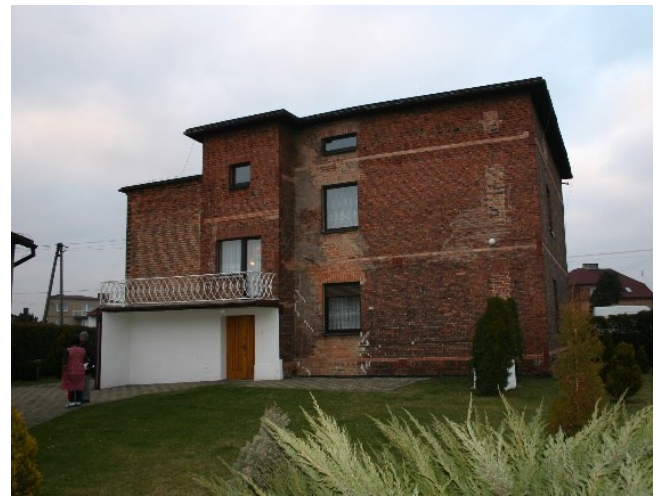

Fig. 3b. View of the building with damaged masonry walls rebuild and strengthen [3].

In addition to continuous deformations (horizontal axial strain and the curvature), a terrain fault directly crossing the building was revealed. The mine have measured the terrain subsidence since 1975. The fault was revealed twice - in 1998 and 2003. The approximate course of the fault is shown in Fig. 2. About $10 \mathrm{~cm}$ settlement covers about $70 \%$ of the building plan. The fault was resulted by the heterogeneous structures of the rock mass and overburden in this area. The variability of hydrogeological conditions characterized by significant changes of groundwater levels were recognized as an additional reasons of the fault.

There were three kinds of damages observed in the building:

- cracks in walls in all rooms on all storeys,

- leaning of the building,

- damp of walls in the basement.

The repair of the object consisted in renovating of the cracked walls and strengthening the structure by using steel ties in the level of floors. Figures $3 \mathrm{a}$ and $3 \mathrm{~b}$ show complemented wall fragments (brighter fragments). The lean of the building was treated as relatively small and thus object was not rectified. Only the floors were leveled and the joinery was adjusted. The building is still in operation.

\subsection{Five-storey RC prefabricated buildings located in the terrain step zone}

The presented case was prepared on the basis of the article [4]. The residential buildings were made in the large-panel technology JW-66/P2. Two five-storey buildings had a projection of $73.56 \times 11.49$ meters and a total height of $15.64 \mathrm{~m}$ (from ground level). Due to the predicted continuous deformation of category III, each building consisted of six independent and relatively small segments with a plan view similar to a square (denoted with symbols $73 \mathrm{~A}-\mathrm{F}$ and $73 \mathrm{G}-\mathrm{M}$ - see Fig. 5). As a protection against mining deformations, an independent foundations were constructed under each segment. They were constructed in the form of slab-on-grade foundation with additional common continuous footing under each two dilatation walls (belonging to adjacent segments). Both, slab and continuous foundation, were designed and reinforced considering actions related to additional impacts arising due to continuous deformations of subsoil. In some segments basements walls were designed and made as reinforced concrete, partly prefabricated with monolithised joints (73A to 73D), while the others were fully made as made in-situ (73E to $73 \mathrm{M})$. Walls of above-ground storeys were made of typical for the system prefabricated large-panels with reinforced joints, strengthening due to mining influences. The layout of the walls for a repetitive storey is shown in Figure 4. 
Geological expertise carried out after the completion of the estate have revealed the occurrence of many tectonic faults in this area. In addition, about $200 \mathrm{~m}$ north of buildings there is a railway line with a meridian course. It was covered against mining damages using technique known as protective pillar. The whole mining operation took place north of the protection pillar zone. This caused activation of faults due to the concentration of stresses in the rock mass. In the past $(1988,1991$ and 1995), 8 latitudinal terrain steps with height from $0.05 \mathrm{~m}$ to $0.5 \mathrm{~m}$ were registered. Fig. 5 shows faults in the area of estate. The most endangered by terrain thresholds are segments $J$ and $C$, under which the height of steps amounted to $0.5 \mathrm{~m}$ and $0.2 \mathrm{~m}$ respectively.

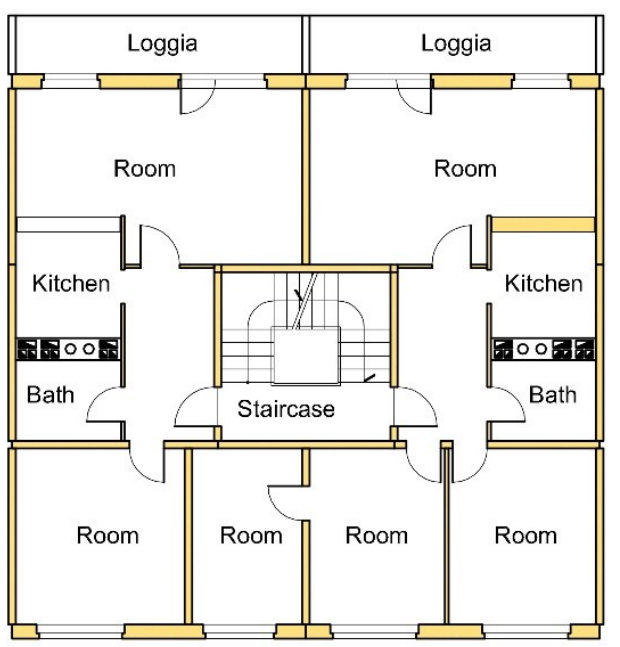

Fig. 4. Plan view of the segment typical storey [4].

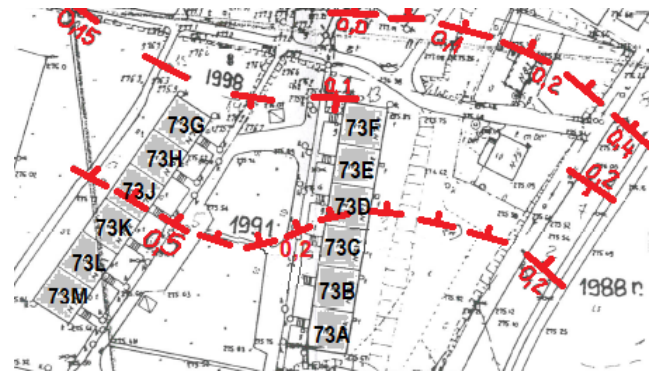

Fig. 5. Terrain faults with regard to buildings location [4].

Leveling measurements in the level above the basement floor showed very significant uneven settlements. The most distinct settlement differences were concentrated in the vicinity of segments $C$ and $J$ (Fig. 6 and 7). The largest displacements correspond to the course of the fault (shown in Fig. 5). Structural damages were concentrated in the basement storey, where the cracks in reinforced concrete walls reached $20 \mathrm{~mm}$. In above-ground storeys, cracks were distinctly smaller and occurred in joints of prefabricated elements - mainly between walls and floor. An exemplary cracks pattern is shown in Fig. 8.

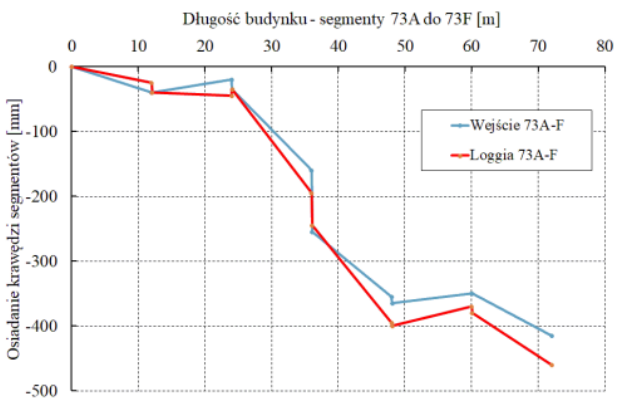

Fig. 6. Settlement of segments $73 \mathrm{~A}$ to $73 \mathrm{~F}$ as a result of the levelling [4].

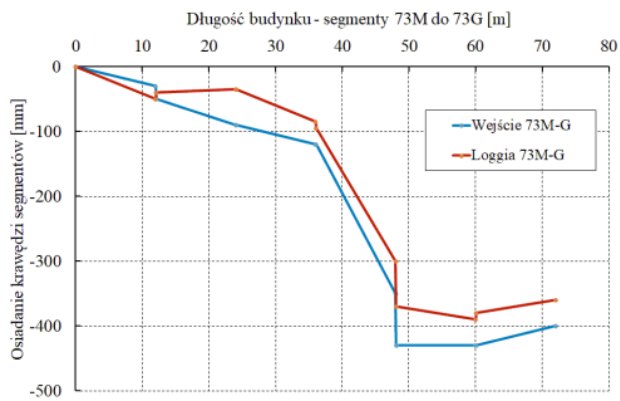

Fig. 7. Settlement of segments $73 \mathrm{M}$ to $73 \mathrm{G}$ as a result of the levelling [4].

The additional effect of uneven settlement was the varied inclination of adjacent segments. Those located on the south side pushed the subsequent ones on the north. 
Large repair costs induced the decision on the demolition of two the most endangered segments. The costs of repair works including rectification were taken into account in economic analysis. The fact that further exploitation was planned in this area and reveal of terrain steps would be very likely, also had some influence on the difficult decision. Demolition works are shown in Fig. 9.

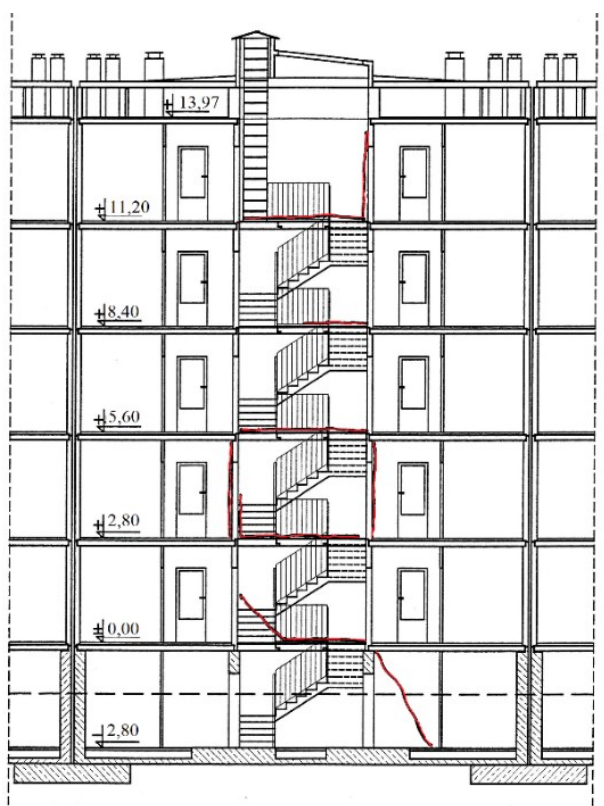

Fig. 8. Cracks pattern in prefabricated panels and joints - segment 73D [4].

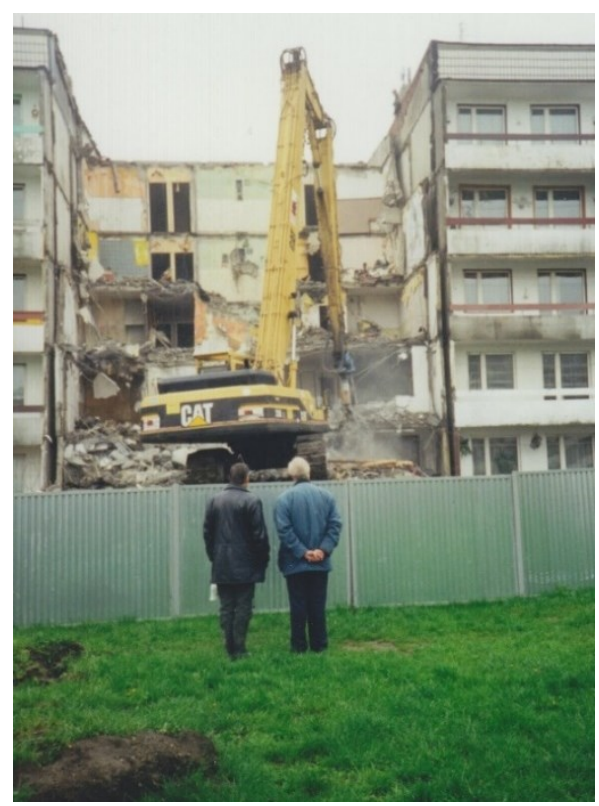

Fig. 9. Demolishion works - segment 73D.

\subsection{Damage to infrastructure as a result of the landslide formation}

The presented discontinuous deformation of the surface type was arisen in the city center, in a quiet district of single-family houses. The origin of such deformations in this area is related to the earlier multiple exploitation of coal seams in this region. The fractured rock mass allows air to enter the exploited coal residue in the rock mass. In combination with high pressure it can lead to fire self-ignition. Fire control is very troublesome because of difficulties with fire zone localization. After completing this process, emptiness arises in the rock mass. With some delay, the load capacity of the rocks over the emptiness may be exhausted. It can be activated by various factors, sometimes not directly related to mining exploitation.

The described landslide was created during one night in the middle of the street. The vertical displacements difference exceeded $1.2 \mathrm{~m}$ - see Figure 10. Car workshop building located in the vicinity has been seriously damaged. The statically determinant load-bearing steel structure of the hall was not damaged, but it underwent considerable deformations. Large deformation of non-bearing filling walls supported on the strip foundation caused fractures and cracks opened up to $2.5 \mathrm{~cm}-$ see Fig. 11. The floor of the workshop was strongly deformed, and its further use became impossible. The owner had received compensation for the resignation of the workshop use. 


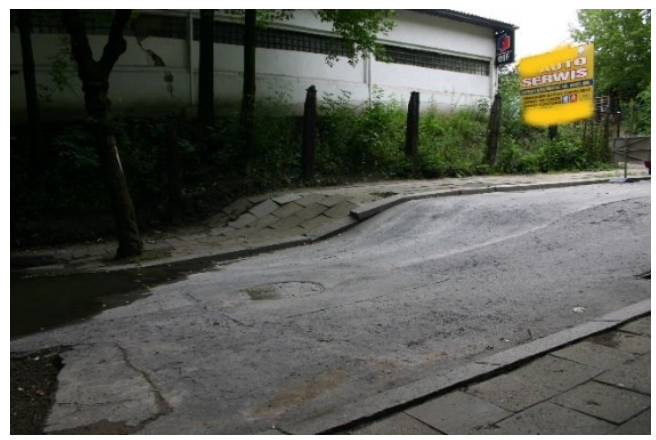

Fig. 10. Landslide crossing the street.

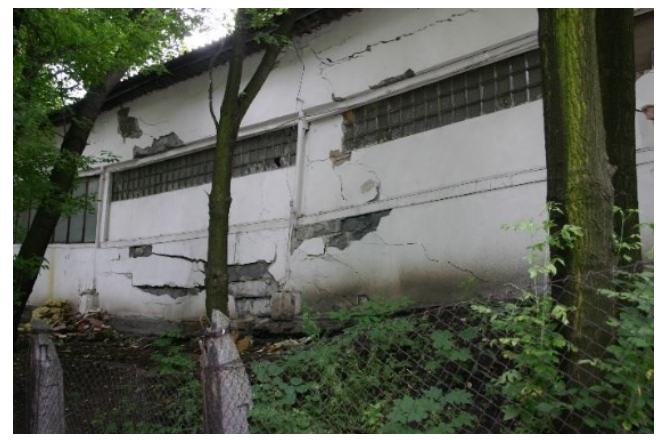

Fig. 11. Damages of the external walls of hall building.

\section{Constructing buildings endangered with the occurrence of discontinuous terrain deformations}

The parameters set out in Table 1 determine the method of proper selection of the structural system for buildings designed in the area of discontinuous deformations. They are as follows:

- area of discontinuous deformation in case of planar deformations,

- bottom level of depression or landslide - planar deformations,

- the height of the terrain step - linear deformations,

- width of the crevice - linear deformations.

\subsection{Assumptions for the structural systems of buildings exposed to discontinuous deformations}

The choice of structural systems in areas subjected to terrain discontinuous deformations is strongly dependent on the relation between the size of the object itself and the magnitude of the forecasted deformation. Depending on the building size, it is necessary to choose the right method of its protection. The following types of buildings can be distinguished [5]:

- pavilions with or without basement,

- mid-rise buildings,

- high-rise buildings,

- tower objects.

A separate group consists of buildings erected in conventional wall technology, both for residential purposes and public use as well.

Pavilion buildings, usually extensive in plan, are sensitive to the influence of both planar and linear deformations. The risk in this case is the possibility of collapse of a single column or group of columns (Fig. 12). The magnitude of the threat depends on the expected depth of the sinkhole. Small buildings (small dimensions in plan) are additionally threatened with the possibility of sliding deep into the sinkhole, especially when its size is significant. Adaptation of pavilion buildings for taking the effects of discontinuous deformations is very difficult due to the low spatial rigidity of the structure with a relatively large size in a plan.

In the case of framework buildings when predicted planar deformations are small in a size, appropriate protection of a structure is possible. It may consist of ties suspending footing together with a column to neighboring bearing systems. To achieve efficiency of 
the protection system the size of the forecasted discontinuous deformations (diameter of the planar deformation) should not exceed the axial spacing of the structural system.

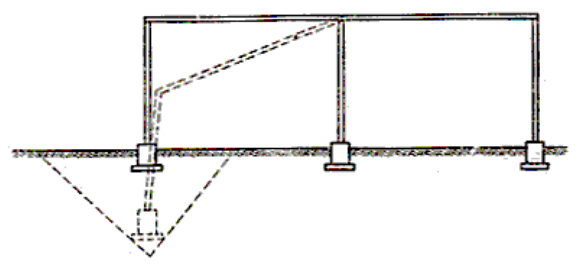

Fig. 12. Settlement of a single column in a pavilion prefabricated building [5].

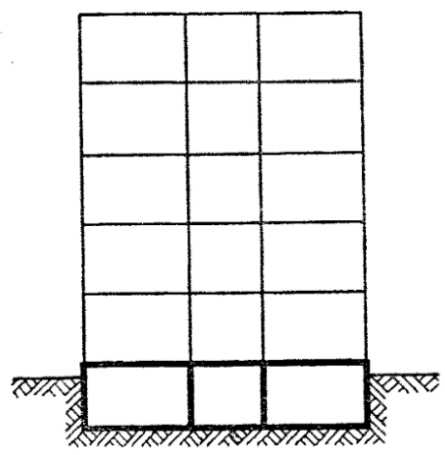

Fig. 13. A multi-storey building on a cellular raft foundation [5].

Mid-rise multi-storey buildings are usually constructed with a basement storey. The execution of a rigid cellular raft foundation (foundation box) significantly reduces the sensitiveness of the object to the effect of discontinuous terrain deformations (Fig. 13). Even in the absence of a rigid foundation, the deep-beam members of structural system are also able to transfer small planar deformations. In this case the wall hangs over the lowering ground thanks to activation of arching effect (Fig. 14). The location of the hole or landslide edge with regard to building base is very important due to equilibrium of the whole object. The location within the object's corner or edge is particularly dangerous and may lead to damages of curtain walls. In the case when the area of sinkhole cover more than $35 \%$ of the building's area, the building tilt can be expected. It may be also accompanied by sliding of building down to the bottom of the sinkhole (Fig. 15).

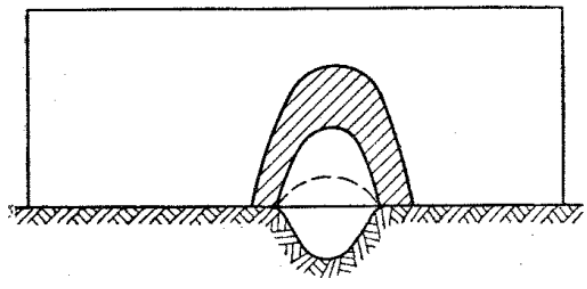

Fig. 14. Wall exibited an arching effect [5].

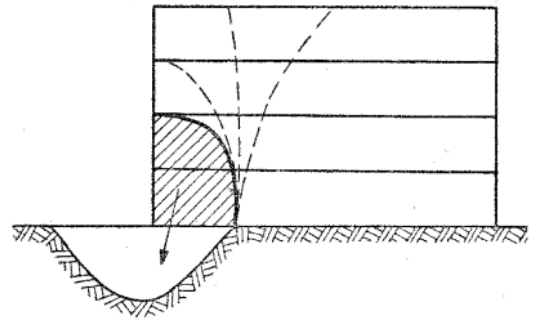

Fig. 15. Unfavorable location of the sinkhole leading to separation of curtain wall and sliding object down [5].

High-rise buildings, due to their nature, produce the significant soil loads. They usually have slab or cellular raft foundations (Fig. 16). The main threat is related to the possibility of building leaning. The inclination of the building on a rigid foundation does not cause any significant redistribution of internal forces in the substructure. However, the lean of whole building leads to inclination of floors, changes of door and window opening shapes and therefore it is often the main reason disturbing the comfortable use of the object. In multisegment buildings, the lean affects the need to predict wide expansion joints that prevent neighboring segments from coming into contact. 
Tower objects lead to significant soil loads due to their function (e.g. water reservoirs). The foundations usually have the form of a cellular raft, quite often enlarged in relation to the ground floor projection (Fig. 17). The occurrence of the discontinuous deformation can significantly influence the lean of the building and leading to losing object serviceability properties.

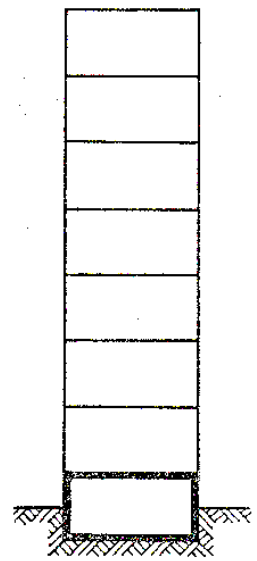

Fig. 16. High-rise buildings supported on cellular raft foundation [5].

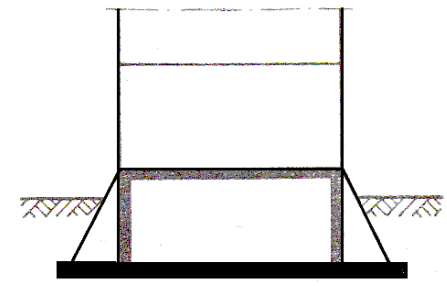

Fig. 17. Tower object supported on widened cellular raft with buttresses [5].

Buildings with load-bearing walls system made in conventional technology are exposed to the influence of discontinuous deformations. Their sensitiveness is related to applied materials and detailed technical solutions. Old buildings erected many years ago without currently used reinforced concrete members (footings, ties, lintels, cores) are exposed to significant damages even when deformations are classified as small. There are many such buildings erected about 50 years ago with foundations made of stones or in form of brickwork.

The implementation of reinforced concrete for footings and floors improves the rigidity of the structural system and reduces damages intensity. Partial suspension of foundations over the terrain step or sinkhole is not followed by severe damages. Further improvement of resistance can be achieved thanks to creation of a system composed of horizontal structural members (footings and floors) joined with hidden columns (RC cores) filled with masonry walls. Such a structural system provides significant increase of building spatial rigidity. Such a strengthen buildings are less vulnerable to partial or total damage of the structure. The complementary solution the lowest storey can always be constructed in the form of a rigid cellular raft foundation (foundation box). Nevertheless, it should be remembered that securing the object against damages will not limit its tilt.

\subsection{Stress distribution under the foundation subjected to the influence of discontinuous deformations}

Proper static analysis of the structure behavior under the influence of discontinuous deformations have to be performed considering full interaction between the structural system and subsoil. Subsoil cannot be treat only as a source of forced displacements.

Calculations cannot be carried out using linear-elastic material models for both - soil and structure. High strain intensity requires use of more advanced material models. It is extremely important for more realistic description of soil behavior.

To illustrate such interaction an exemplary 2D analysis have been performed. Normal stress distribution in subsoil directly below the foundation have been shown for various 
localizations of terrain step with regard to the length of strip foundation (covering various part of this foundation). It was assumed that the structure is relatively rigid. The revealing terrain step leads to change of the uniform distribution of normal stress $\sigma$ in the subsoil under the strip foundation. Relation between step localization and stress distribution were widely described in [6] and [7] and shown in Figure 18. In this example, normal stress in subsoil at the building's edge zone exceeds the initial value of the mean normal stresses $\sigma_{\mathrm{m}}$ more than three times (Fig. 18e). In the presented analysis, an isotropic elastic-plastic material model with hardening and softening ([8], [3]) was applied. Soil were characterized by internal friction angle $\Phi=40^{\circ}$ and cohesion $c=0 \mathrm{MPa}$. It is worth to mentioned, that the assumed height of the terrain step amounted to $5 \mathrm{~cm}$ only.

a)

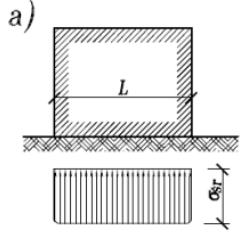

b)

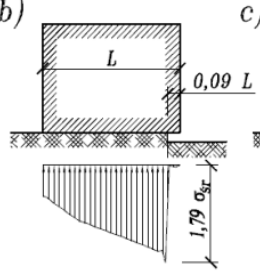

e)

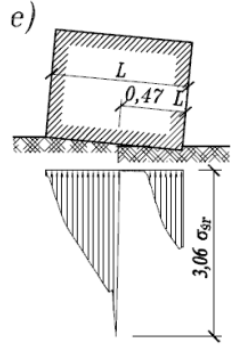

c)

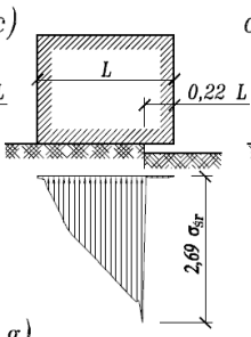

f)

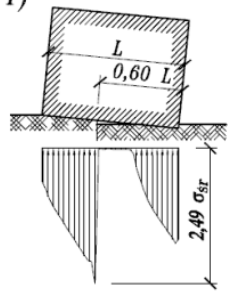

g)

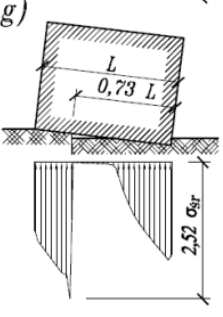

d)

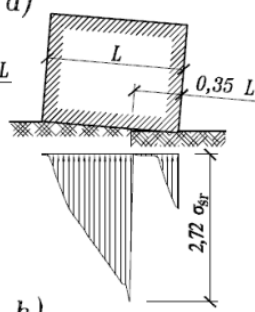

h)

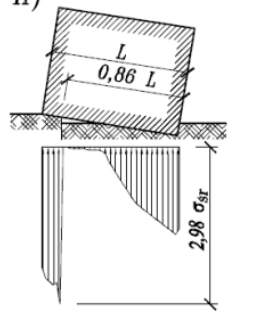

Fig. 18. Normal stress distribution for various localizations of terrain step on the basis [7].

In case of other subsoil parameters and step characteristic, the stress concentration may change slightly. In any case, it is necessary to take into account the possibility of structure leaning even when it is adapted to take over such a load. In order to restore the full object serviceability, it is necessary to take into account the necessity of its rectification.

\section{Summary}

Discontinuous deformations induced by hard coal excavation occur on the terrain surface much less frequently than continuous ones. The intensity and speed of their manifestation causes static but violent effects on building objects localized on the area subjected to this influence. Buildings and other unprotected structures cannot resist efficiently such influences without significant damages, including full destruction of a structure.

The most important influence is the change of support conditions under some parts of foundations. It can be related with uneven settlement of a part of building or creation a gap between foundation and subsoil. The division of discontinuous deformations due to the form (linear or planar) is less important for buildings small in a plan. Much more important is the location of the discontinuity edge in relation to the projection of the foundations, regardless of whether it is the terrain or the edge of the sinkhole.

Protecting the structure against the influence of discontinuous deformations, it is necessary to prepare foundations to the possibility of significant stress concentrations caused by the change of the object's support conditions. The usually unknown location of 
potential discontinuous deformations requires analysis of various scenarios. In some potential conditions, rectification of leaned building would be necessary and must be predicted in project phase as a method of the serviceability restoration.

When analyzing the behavior of the structure in the case of discontinuous deformations, it is necessary to consider cooperation between building and subsoil. In calculations, it is necessary to consider high strains in subsoil in vicinity of the edge of terrain step. To obtained better approximation it is necessary to use software enabling use of elastic-plastic material models for subsoil behavior.

\section{References}

1. W. Janusz, A. Jarosz, Nieciagłe deformacje powierzchni wywołane plytka podziemna eksploatacja górnicza (Proceedings of the Conference „Budownictwo na terenach górniczych o dużych deformacjach powierzchni”, Katowice, 1976) [in Polish]

2. M. Chudek, W. Janusz, L. Zych, Zeszyty Naukowe Politechniki Śląskiej Górnictwo, 141 (1988) [in Polish]

3. L. Szojda, Analiza numeryczna wplywu nieciagłych deformacji podłoża na budynki ścianowe (Wydawnictwo Politechniki Śląskiej, Gliwice, 2010) [in Polish]

4. L. Szojda, Uszkodzenia budynku wielkoptytowego wywołane ujawnieniem się progu terenowego, Proceedings of the $3^{\text {rd }}$ Conference „Obiekty Budowlane na Terenach Górniczych”, PZITB, Katowice-Siemianowice Śląskie, pp. 193-220, 2018) [in Polish]

5. A. Ledwoń, Budownictwo na terenach górniczych (Arkady, Warszawa, 1983) [in Polish]

6. L. Szojda, Sposoby zabezpieczenia budynków ścianowych na wptyw nieciagtych deformacji terenu. (Proceedings of the $1^{\text {st }}$ Conference „Obiekty Budowlane na Terenach Górniczych”, PZITB, Siemianowice Śląskie, pp. 303-331, 2014) [in Polish]

7. L. Szojda, Analiza numeryczna zmian naprężeń w konstrukcji ściany wywołanych nieciagłymi deformacjami podłoża górniczego. J. Civ. Eng. Environ. Arch., 34 (63), pp. 511-522 (2017) [in Polish]

8. S. Majewski, Mechanika betonu konstrukcyjnego w ujęciu sprężysto-plastycznym (Wydawnictwo Politechniki Śląskiej, Gliwice, 2003) [in Polish] 